https://doi.org/10.5817/OS2018-4-6

\title{
Po rusky komunikačne, efektívne a zážitkovo
}

MATEJKO, L': Nová ruština pre samoukov + 1 audio CD. Bratislava: Eastone Books, 2018, 248 s. ISBN 978-80-8109-352-4.

L. Matejko svojím autorským počinom predstavuje všetkým záujemcom o spoznanie ruského jazyka a základných faktov o ruskej histórii a kultúre titul, ktorý je pokračovaním série jazykových učebníc Language Masters, ktoré vydavatel'stvo Eastone Books vydalo za ostatných niekolko rokov. Spracovanie vychádza zo zámeru autora aplikovat' také didaktické metódy a postupy, aby „používatel učebnice aj bez pomoci učitel'a zvládol správnu výslovnost', osvojil si slovnú zásobu a naučil sa gramatiku do takej miery, aby mohol volne komunikovat'v rozličných životných situáciách" (s.8). Cielom autora bolo vytvorit’ aktuálnu, moderne a prakticky spracovanú učebnicu založenú na samostatnom aktívnom nácviku a rozvíjaní jazykovej, rečovej, komunikačnej a prekladatel'skej kompetencie, a taktiež uplatnení funkčného prístupu k prezentácii jazykového materiálu. Adresátmi môžu byt nielen samoukovia, ale aj frekventanti jazykových kurzov pre začiatočníkov, žiaci a študenti, ktorí s učebnicou pracujú na vyučovaní pod odborným pedagogickým vedením a všetci tí, pre ktorých sa stane dobrým spoločníkom i pomôckou na ceste $\mathrm{k}$ spoznávaniu jedného zo svetových jazykov. Práve tento zámer sleduje predkladaná učebnica adresovaná tým záujemcom, ktorí majú ambície zvládnut’ svoje kompetencie v ruskom jazyku na úrovni A1 - A2 podla Spoločného európskeho referenčného rámca pre jazyky (SERR).

Z hladiska štruktúry učebnicu tvorí 15 lekcií a okrem nich učebnica taktiež obsahuje predslov (s. 8 -9), predstavenie ruskej abecedy v podobe tlačených písmen s názvami jednotlivých znakov v prepise do latinky (v hranatých zátvorkách) spolu so stručnými poznámkami o výslovnosti (s. 10 - 11), rusko slovenský slovníček (s. 181-192), riešenia cvičení (s. 193 - 220) a prepisy nahratých textov (s. $221-246)$.

Predpokladom úspechu modernej výučby cudzích jazykov (hlavne určených pre samoukov) je aj kvalitná zvuková nahrávka nositel’ov príslušného jazyka. Tieto atribúty autor recenzovanej učebnice $\mathrm{v}$ plnej miere naplnil a využil. Ozvučenie ruských textov, slovíčok a fráz v bratislavskom nahrávacom štúdiu ARS Studio s hlasmi Ivana Posokhina, Mariny Zverevovej, Kamily Dumnytskej a Petra Šebelu tvorí súčast’ učebnice $\mathrm{v}$ podobe verzie $\mathrm{S} \mathrm{MP}_{3}$.

L. Matejko v predslove (s. 8-9) informuje čitatela o tom, komu je učebnica adresovaná, o niektorých výhodách a nevýhodách príbuznosti dvoch slovanských jazykov (slovenčiny a ruštiny) a uvádza aj stručné poučenie o ruskom prízvuku, pričom kladie dôraz na jeho dôležitost' a zároveň odlišnost’ od slovenčiny. V predslove sa autor stručne zmieňuje aj o cvičeniach a overení nácviku jazykových a rečových kompetencií pomocou správnych riešení uvedených na konci učebnice. 
Prvá lekcia recenzovanej učebnice obsahuje sedem krokov, ktoré študujúceho postupne nenásilnou formou oboznamujú s jednotlivými grafémami ruskej abecedy. V slovných príkladoch autor vhodne uvádza aj prepis do latinky. V šiestom kroku autor osobitne akcentuje výslovnost jotovaných samohlások Ë - Я - Ю a v siedmom čitatela oboznamuje so základmi používania mäkkého a tvrdého znaku. Vo všetkých krokoch sú zaradené rôzne druhy jazykových cvičení so zameraním na nácvik písania znakov ruskej abecedy, a taktiež ich správnej výslovnosti. V časti Základné pravidlá pravopisu $a$ výslovnosti autor $\mathrm{v}$ dvoch prehladných tabulkách uvádza výslovnost̉ samohlások s prízvukom a tých, na ktorých nie je prízvuk. Výslovnost̉ spoluhlások L'. Matejko sumarizuje do niekolkých dôležitých pravidiel (s. 26) a v časti Pravidlá prepisu z ruštiny do slovenčiny prezentuje $\mathrm{v}$ prehladnej tabulke len problémové prípady prepisu znakov ruskej abecedy do latinky. Rôzne lingvistické komentáre a iné rady Olgy a Sašu, hlavných hrdinov príbehu obsiahnutého vo všetkých textoch nielen náležite doplñajú výklad jednotlivých pravidiel, ale zároveň ho grafickým spracovaním spestrujú, a tým čitatela motivujú pokračovat dalej v štúdiu. Vysoko oceňujeme skutočnost', ako sa autorovi podarilo prezentovat problematiku prvej lekcie tak, aby bola prístupná a pochopitelná pre všetkých tých záujemcov, komu je učebnica adresovaná.

Ďalšie lekcie sú tažiskové a okrem prvej sú založené na práci s dôkladne vybranými dialogickými a monologickými textami. Niektoré texty obsahujú len samostatné vetné konštrukcie (napr. na s. 38 a 51), niekolko možných fráz pri telefonickom rozhovore (s. 162), alebo v jednom prípade (s. 85) ide o kalendár ruských štátnych sviatkov. V súvislosti s výberom textov si dovolujeme ocenit autorov zámer nečlenit ich tematicky samostatne podla tradičných konverzačných tém, ale v rámci jednotlivých lekcií vytvorit jeden kompaktný celok mapujúci životný príbeh mladého ruského podnikatela Alexandra Andrejeviča Tretiakova a jeho priatelky Olgy. Pozitívne hodnotíme obsahové zameranie, aktuálnost vybraných textov (texty v lekciách 12-15 s tematikou ekonomiky, obchodu, financií a obchodnej korešpondencie považujeme za excelentné) a v neposlednom rade aj ich rozsah a počet (v lekciách 2, 3, 4, 5, 6, 11 a 12 po dva texty, v lekciách 7, 8, 9, 10 po jednom texte a v lekciách 13, 14, 15 po tri texty). Ku každému textu je pripojený aj slovníček so slovenskými prekladovými ekvivalentmi. Na utvrdenie niektorých dôležitých slovných spojení i celých vetných konštrukcií autor $k$ väčšine textov doložil aj čast Запомните! V rámci gramatického učiva sa nám žiada vyzdvihnút jeho jasné a výstižné spracovanie s nenásilnou formou osvojenia, s doloženými vhodnými príkladmi a celkovým prehladným grafickým spracovaním. Spestrenie gramatickej časti predstavujú $v$ bublinách po slovensky uvedené doplňujúce gramatické komentáre a iné rady samotného Sašu.

L. Matejko venuje náležitú pozornosț aj výberu rôznych druhov jazykových a rečových cvičení. S potešením konštatujeme, že tejto úlohy, ktorá pri tvorbe učebníc cudzieho jazyka tvorí neoddelitelnú a podstatnú čast', sa zhostil na výbornú. 
Ako celok sú cvičenia vyvážené, čím vytvárajú kompaktný celok určený na nácvik a rozvíjanie jazykovej, rečovej, komunikačnej a prekladatel'skej kompetencie. V neposlednom rade sa nám žiada vyzdvihnút aj interkultúrny a interpersonálny aspekt niektorých cvičení reflektujúcich potreby a záujmy súčasných mladých ludú. Na tomto mieste chceme vyzdvihnút skutočnost', že súčasné trendy v podobe zavádzania interkultúrnej komunikácie do výučby cudzích jazykov, kedy sa didaktika cudzích jazykov nezameriava len na výučbu samotného jazyka, ale aj na sprostredkovanie vedomostí o kultúre a histórii daného národa sú nezvratné a právom opodstatnené aj $\mathrm{v}$ recenzovanej učebnici.

S radostou sme uvítali aj skutočnost', že autor pri tvorbe cvičení zameraných okrem nácviku jazykových a rečových zručností študenta nezabudol ani na starú dobrú klasiku prekladových cvičení, ktoré sú súčastou všetkých tažiskových lekcií. Správnost̉ prekladu si môžu študenti overit v klúči. Domnievame sa, že nácvik prekladatelskej kompetencie, ktorý vychádza z tradičnej gramaticko-prekladovej metódy výučby cudzích jazykov má i v súčasnosti svoje opodstatnenie. Súhrnne konštatujeme, že všetky cvičenia sa svojím praktickým spracovaním jednoznačne pozitívne podielajú na celkovej vel’mi dobrej úrovni recenzovanej učebnice.

Velmi kladne hodnotíme zaradenie predtextových imitačných jazykových cvičení v lekciách $2-5$, ktoré sú hlavne pri počiatočnom štúdiu osvojovania si cudzieho jazyka velmi dôležité nielen pre samoukov. Na lepšie pochopenie niektorých reálií autor do niektorých lekcií adekvátne zaradil aj konkrétne príklady ruskej rečovej etikety so slovenskými prekladovými ekvivalentmi (s. 36, 43, 62, 67, 80), doplnil kulturologický (s. 87 čast̉ Prečo majú v Rusku Silvestra 13. januára?; s. 135-137 čast̉ Dobrú chut! Приятного аппетита!); krajinovedný (s. 90 čast Železničná doprava) a lingvistický komentár (s. 100 čast’ Pozor na prízvuk!; s. 130 čast̉ Kedy sa používa большой a kedy великий + Kedy sa používa долгий a kedy длинный; s. 179 čast Ako sa @ povie po rusky?). Na s. 108 L. Matejko ponúka študujúcim aj základné rady, akýsi stručný návod, ako prekladat anekdoty.

Neodmyslitelnou súčastou učebníc cudzích jazykov je aj ich grafická úprava. V prípade recenzovanej učebnice môžeme konštatovat', že zodpovedá európskym štandardom. Učebnica je spracovaná prehladne, motivujúco, k čomu v neposlednom rade prispieva aj jednotný typ písma s náležitou rôznorodou velkostou a farebným odlíšením, napr. v nadpisoch či zadaniach cvičení. K celkovému velmi dobrému dojmu prispievajú aj výstižné farebné autorské ilustrácie Zuzany Jakubíkovej.

V závere konštatujeme, že recenzovaná učebnica je metodicky dobre usporiadaná, prehladná a prístupná. Jej aktuálne a moderné spracovanie je vynikajúcim počinom L'. Matejka, ktorý obohatil knižný trh o pomerne úzku paletu pôvodných učebníc určených pre začiatočníkov pri štúdiu ruského jazyka ako cudzieho v podmienkach slovenskej školy. Dovolíme si tvrdit, že od vydania učebnice (apríl 2018) si už 
v súčasnom období určite našla svojho adresáta. Učebnicu považujeme za hodnotné dielo, ktoré predstavuje pozitívny vklad do problematiky výučby cudzích jazykov.

Dúfajme, že v blízkej budúcnosti nás autor poteší vydaním pokračovania danej učebnice pre mierne pokročilý stupeň ovládania ruského jazyka $\left(\mathrm{B}_{1}-\mathrm{B}_{2}\right)$.

fán Gallo

https://doi.org/10.5817/OS2018-4-7

\section{Новое учебное пособие по морфологии русского языка}

АРХАНГЕЛЬСКАЯ, А., СЛОВАК,В.: Морфология современного русского языка в сопоставлении с чешским. 1-ое издание. Оломоуц: Издательство Университета им. Ф. Палацкого, 2017. 194 с. ISBN 978-80-244-5249-4.

К началу XXI века резко ускорились изменения в русском языке. Существенные изменения произошли в фонетике и произношении, морфологии и синтаксисе, словообразовании и лексике, так как язык реагирует на все изменения в жизни его носителей. Эти изменения, касающиеся морфологии современного русского языка, освещены в рецензируемом учебном пособии. Оно предназначено для студентов филологических специальностей университетов Чешской Республики, изучающих русский язык как свою специальность. Подготовка и издание настоящего учебного пособия было осуществлено при целевой финансовой поддержке Министерства образования, молодежи и спорта Чешской Республики и Фондом развития Университета им. Ф. Палацкого проекта Vytvoření moderní výukové platformy studia ruštiny na FF UP, FRUP_2017_053. Пособие содержит две части - теоретическую и практическую. Теоретическая часть подготовлена доктором филологических наук, профессором кафедры славистики философского факультета Оломоуцкого университета Аллой Архангельской, практическая часть - докторантом той же кафедры славистики Вацлавом Словаком.

Теория морфологии в пособии рассмотрена с учетом русской и чешской грамматической традиции и актуальных исследований последних десятилетий. В ее основе - системный взгляд на природу языка, взаимодействие его подсистем, системные и асистемные проявления. При изложении материала авторы стремились показать многообразие точек зрения на рассматриваемые проблемы, обозначить и сопоставить подходы к определенному морфологическому явлению в русской традиции и чешской русистике. Исходя из текста теоретической части настоящего пособия следует, что в каждом 